\title{
Comparison of Serum Fibrin-Fibrinogen Degradation Products with Carcinoembryonic Antigen as Biomarkers for Colon Cancer
}

Hee Jin So ${ }^{1}$, SeokIl Hong ${ }^{1,2}$, Jin Kyung Lee $^{1,2}$, Yoon Hwan Chang $^{1,2}$, Jin Hee Kim ${ }^{1}$, and Young Jun Hong ${ }^{1,2}$

${ }^{1}$ Department of Laboratory

Medicine, Korea Cancer

Center Hospital, Seoul;

${ }^{2}$ Radiation Cancer

Medicine, University of

Science and Technology,

Daejeon, Korea

Corresponding author:

Young Jun Hong

Department of Laboratory

Medicine, Korea Cancer Center

Hospital, 75 Nowon-ro, Nowon-

gu, Seoul 139-706, Korea

Tel: $+82-2-970-2492$

Fax: +82-2-973-7143

E-mail: clinchem@kcch.re.kr
Background: Colon cancer is the second most common cancer in males and fourth most common in females in Korea. The levels of serum fibrin-fibrinogen degradation products (FDP) are elevated in many malignancies due to haemostatic alterations resulting from carcinogenesis. We compared serum FDP with carcinoembryonic antigen (CEA) to assess whether FDP has a diagnostic value for colon cancer.

Methods: A total of 177 serum samples from 95 colon cancer patients and 82 healthy controls were provided by the Korea Cancer Center Hospital biobank. Serum FDP levels were measured using the DR-70 detection kits (AMDL, USA) and the levels of serum CEA were measured using the Roche E170 Analytics (Roche Diagnostics, Germany).

Results: The mean serum FDP and serum CEA levels were significantly higher in the cancer patient group (FDP, $1.65 \pm 1.44 \mu \mathrm{g} / \mathrm{mL}$; range, 0.36 to 9.48 ; CEA, $99.99 \pm 321.74 \mathrm{ng} /$ $\mathrm{mL}$; range, 1.46 to $2,170.00$ ) than in the control group (FDP, $0.58 \pm 0.46 \mu \mathrm{g} / \mathrm{mL}$; range, 0.02 to $3.27, P<0.05$; CEA, $1.66 \pm 1.18 \mathrm{ng} / \mathrm{mL}$; range, 0.20 to $6.38, P<0.05)$. The receiver operating characteristic curve for FDP showed $80 \%$ clinical sensitivity and $83 \%$ specificity with an optimal cut-off of $0.81 \mu \mathrm{g} / \mathrm{mL}$, while that for CEA exhibited $84 \%$ sensitivity and $94 \%$ specificity with a cut-off of $3.51 \mathrm{ng} / \mathrm{mL}$. The area under the curve was 0.87 and 0.96 for serum FDP and CEA, respectively. A combination of the two markers showed $90 \%$ clinical sensitivity and $92 \%$ specificity for colon cancer.

Conclusions: The diagnostic sensitivity for colon cancer was increased by using a combination of FDP and CEA.

(J Lab Med Qual Assur 2014;36:99-106)

Key Words : Fibrin fibrinogen degradation products, DR-70 immunoassay, Colonic neoplasms, Carcinoembryonic antigen, Biological markers

Received April 3, 2014, Revision received May 16, 2014, Accepted May 24, 2014
단백으로 이루어진 carcinoembryonic antigen (CEA)이다. $\mathrm{CEA}$ 는 위장관암에서 가장 흔히 사용되는 표지자이며, 특히 대장암에서 특이도가 높아 수술 전 검사로 많이 이용되고, 수 술 후 재발 여부나 치료 후 추적관찰, 전이성 병변의 모니터로 도 사용된다. 그러나 낮은 민감도로 인하여 종양의 선별검사로 는 추천되지 않는다[4].

최근 간암, 유방암, 위암, 췌장암 등 여러 암종에서 정량적 으로 측정된 혈청 fibrin-fibrinogen degradation products (FDP)의 범종양표지자(pantumour marker)로서의 활용가 
능성이 제기되고 있다[5-13]. 대장암 환자에서도 지혈과정의 변화가 흔하게 일어나며 응고과정과 섬유소 용해과정의 과활 성화가 질병의 임상적 진행과 관련이 있다고 보고되었다 14 20]. 그러나 기존의 연구에서는 대장암 환자군의 표본 수가 30 이하로 소규모였고, $\mathrm{FDP}$ 측정목적으로 혈장 $\mathrm{D}-$ 이합체를 이 용한 검사가 많았다. 기존의 $\mathrm{FDP}$ 검사법은 혈장 검체를 이용 한 라텍스응집법, 면역혼탁측정법, 반사광측정법 등으로 이들 은 $\mathrm{FDP}$ 중 주로 $\mathrm{D}$ 절편과 $\mathrm{E}$ 절편을 정량적으로 측정하는 검사 다. 한편 ELISA를 이용한 혈청 FDP측정법은 정상 플라스민 분해에 의해서는 생성되지 않는 종양과 관련되어 생성된 $\mathrm{FDP}$ 까지 포함하여 측정하는 방법이므로 기존의 FDP검사법들에 비해 좀 더 높은 민감도를 제공할 수 있다[8]. 본 연구에서는 모수적 검정이 가능한 숫자의 대장암 검체를 이용하여 ELISA 검사법을 통해 $\mathrm{FDP}$ 농도를 측정하고 전통적인 대장암 표지자 인 $\mathrm{CEA}$ 와 비교함으로써 $\mathrm{FDP}$ 의 임상적 유용성을 알아보고자 하였다.

\section{재료 및 방법}

\section{1. 연구대상}

본 연구는 2006년부터 2010년까지 병원에서 진단된 대장암 환자 혈청 검체로서, 한국원자력의학원 국가방사선혈액자원 은행에서 보유하고 있는 수술 전 검체 95건을 대상으로 진행 하였다. 대조군 역시 한국원자력의학원 국가방사선혈액자원 은행이 보유하고 있는 건강인 82 명의 혈청을 분양받아 사용하 였다. 대장암 환자군의 중앙연령은 67세(범위, 34-90세)로, 남 자가 55 명, 여자가 40 명이었다. 건강대조군은 중앙연령 45 세 (범위, 28-71세), 남녀비율 7.2:1이었다(Table 1). 본 연구는 기관생명윤리위원회로부터 연구승인을 받았다(K-1305-002026).

\section{2. 연구방법}

1) Fibrin-fibrinogen degradation products 농도측정

FDP 농도는 DR-70 진단키트(AMDL, Tustin, CA, USA) 를 이용하고 $\mathrm{Wu}$ 등[9]의 연구에서 사용된 방법을 참고하 여 측정하였다. DR-70분석법은 여러 형태로 존재하는 $\mathrm{FDP}$ 를 ELISA방식의 표준 샌드위치면역분석법으로 한꺼번에 측 정하는 방법이다. 모든 혈청은 희석용액으로 200 배 희석하여 각 well에 $100 \mu \mathrm{L}$ 씩 분주한 후, 실내 온도에서 30분간 보관하 였다. 이후에 $300 \mu \mathrm{L}$ 완충용액으로 6 번 세척한 후, 효소 항체 접합체 $100 \mu \mathrm{L}$ 를 분주하고 다시 30분간 보관 후 세척하였다. $100 \mu \mathrm{L}$ 의 3, 3', 5, 5'-tetramethylbenzidine 기질용액을 각
Table 1. Characteristics of the study population

\begin{tabular}{lcl}
\hline Characteristic & $\begin{array}{c}\text { Colon cancer } \\
\text { patients } \\
(\mathbf{n}=95)\end{array}$ & $\begin{array}{c}\text { Healthy } \\
\text { controls } \\
(\mathbf{n}=\mathbf{8 2})\end{array}$ \\
\hline Gender & $55(58)$ & $72(88)$ \\
Male & $40(42)$ & $10(12)$ \\
Female & $67(34-90)$ & $45(28-71)$ \\
Median age (yr, range) & & \\
Tumour site & $26(27)$ & \\
Colon & $13(14)$ & \\
Sigmoid & $8(8)$ & \\
Rectosigmoid & $48(51)$ & \\
Rectum & & \\
Histology & $88(93)$ & \\
Adenocarcinoma & $2(2)$ & \\
Mucinous adenocarcinoma & $3(3)$ & \\
Signet ring cell adenocarcinoma & $1(1)$ & \\
Neuroendocrine carcinoma & $1(1)$ & \\
Unknown & $29(31)$ & \\
Metastasis & $23(24)$ & \\
No metastasis & $40(42)$ & \\
Adjacent lymph node & $3(3)$ & \\
Remote metastasis & & \\
Unknown & & \\
\hline
\end{tabular}

Values are presented as number (\%).

well에 추가하고 15 분간 발색과정 후, 정지 용액을 첨가한 다 음 $450 \mathrm{~nm}$ 에서 흡광도를 측정하였다.

2) Carcinoembryonic antigen 농도측정

혈청 CEA 농도는 전기화학발광면역분석법(electrochemiluminescence immunoassay)을 이용한 Roche Modular Analytics E170으로 측정하였다(Roche Diagnostics GmbH, Mannheim, Germany) [21].

3) DR-70 진단키트 정밀도

DR-70 진단키트의 정밀도 평가를 위해 CLSI/NCCLS EP5-A2와 EP15-A2를 참고하여 kit에 포함된 2가지 농도의 정도관리물질 및 2 가지 농도의 혼주혈청을 사용하여 각각 3 회 씩 3일간 반복 측정하였다.

4) 통계분석

환자군과 건강대조군의 $\mathrm{FDP}$ 와 $\mathrm{CEA}$ 의 평균 비교를 위하 
여 집단의 $\mathrm{n}$ 수가 모두 30 이상이므로 모수적 검증인 Student t-test를 시행하였다. FDP 및 $\mathrm{CEA}$ 에 대한 최적의 값을 receiver operating characteristic (ROC) 곡선을 이용하여 측 정하였다. 통계 프로그램은 SALT ver. 2.0 (ISTECH, Seoul, Korea) 소프트웨어를 사용하였고, $P$ 값이 0.05 미만일 경우를 통계적으로 유의하다고 판단하였다.

\section{결과}

\section{1. 종양표지자들의 혈청 농도 비교}

평균 $\mathrm{FDP}$ 농도는 환자군에서 $1.65 \pm 1.44 \mu \mathrm{g} / \mathrm{mL}$ (범위, $0.36-9.48 \mu \mathrm{g} / \mathrm{mL}$ ), 건강대조군에서 $0.58 \pm 0.46 \mu \mathrm{g} / \mathrm{mL}$ (범위, 0.02-3.27 $\mu \mathrm{g} / \mathrm{mL}$ )로 측정되어 환자군이 건강대조군보다 통계 적으로 유의하게 높았다 $(P<0.05)$. $\mathrm{CEA}$ 의 평균 농도는 환자군 에서 $99.99 \pm 321.74 \mathrm{ng} / \mathrm{mL}$ (범위, $1.46-2,170.00 \mathrm{ng} / \mathrm{mL}$ ), 건 강대조군에서 $1.66 \pm 1.18 \mathrm{ng} / \mathrm{mL}$ (범위, $0.20-6.38 \mathrm{ng} / \mathrm{mL}$ )로 측정되어, 환자군이 건강대조군보다 통계적으로 유의하게 높 았다 $(P<0.05)$ (Fig. 1). 대장암 환자군 내의 종양부위와 전이 정도에 따른 $\mathrm{FDP}$ 와 $\mathrm{CEA}$ 의 유의한 농도 차이는 없었다.

\section{Receiver Operating Characteristic 커브를 이용한 종양표 지자들의 진단적 성능평가}

$\mathrm{ROC}$ 커브상에서 민감도와 특이도의 손실 없이 최대효율을 보이는 $\mathrm{FDP}$ 와 CEA의 컷오프는 각각 $0.81 \mu \mathrm{g} / \mathrm{mL}, 3.51 \mathrm{ng} /$ $\mathrm{mL}$ 이었다. $\mathrm{FDP}$ 의 컷오프를 $0.81 \mu \mathrm{g} / \mathrm{mL}$ 로 할 때 대장암 진
단의 민감도는 $80 \%$, 특이도는 $83 \%$ 였다(Fig. 2). CEA의 경우 컷오프를 $3.51 \mathrm{ng} / \mathrm{mL}$ 로 할 때 대장암 진단의 민감도, 특이도 는 각각 $84 \%, 94 \%$ 였다(Fig. 2). 두 표지자를 병용하였을 때 민감도는 $90 \%$, 특이도는 $92 \%$ 로 민감도가 증가하였다(Table 2). FDP ROC 커브에서 곡선하면적(area under the curve, AUC)은 0.87 (95\% confidence interval [CI], 0.82 to 0.94), CEA ROC 커브에서의 AUC는 0.96 (95\% CI, 0.94 to 0.98) 이었고, 두 표지자를 병용하였을 때의 AUC는 0.97 (95\% CI, 0.95 to 0.99 )이었다(Fig. 2).

\section{Fibrin-Fibrinogen Degradation Products와 Carcinoem- bryonic Antigen의 상관성}

대장암 환자군에서 $\mathrm{FDP}$ 와 $\mathrm{CEA}$ 사이의 유의한 상관성은 관 찰되지 않았다(Pearson's correlation test: $\mathrm{n}=95, \mathrm{R}=0.094$, $P=0.365$ ) (Fig. 3).

\section{DR-70 진단키트 정밀도평가}

다양한 농도의 정도관리물질과 혼주혈청에 대한 변이계수 는 Table 3과 같다. 저농도와 고농도 정도관리물질, 저농도와 고농도 혼주혈청의 검사 내 변이계수는 $4.6 \%, 6.6 \%, 3.6 \%$, $4.6 \%$ 이었고, 총 변이계수는 $13.1 \%, 6.8 \%, 14.1 \%, 8.2 \%$ 이었 다.

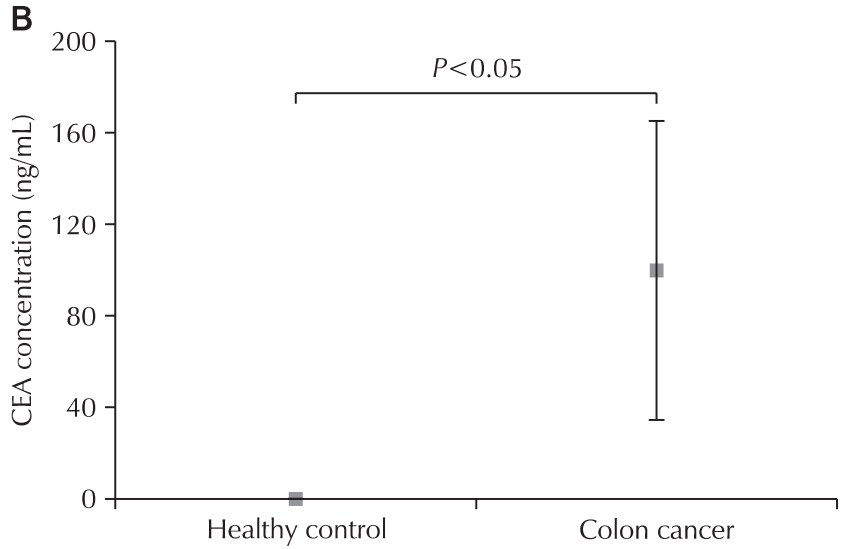

Fig. 1. Comparison of tumor marker between colon cancer group and healthy control group. The lineindicates $95 \%$ confidence interval of tumor marker in each group. The box refers to mean level. (A) Themean value of fibrin-fibrinogen degradation products (FDP) was significantly higher in colon cancer group (mean, $1.65 \pm 1.44 \mu \mathrm{g} / \mathrm{mL}$; range, 0.36 to $9.48 \mu \mathrm{g} / \mathrm{mL}$ ) than in healthy control group (mean, $0.58 \pm 0.46 \mu \mathrm{g} / \mathrm{mL}$; range, $0.02-3.27 \mu \mathrm{g} / \mathrm{mL} ; P<0.05$ ). (B) The mean value of carcinoembryonic antigen $(\mathrm{CEA}$ ) was significantly higher in coloncancer group (mean, $99.99 \pm 321.74 \mathrm{ng} / \mathrm{mL}$; range, 1.46 to $2,170 \mathrm{ng} / \mathrm{mL}$ ) than in healthy control group (mean, $1.66 \pm 1.18 \mathrm{ng} / \mathrm{mL}$; range, 0.2 to $6.38 \mathrm{ng} / \mathrm{mL} ; P<0.05$ ). 

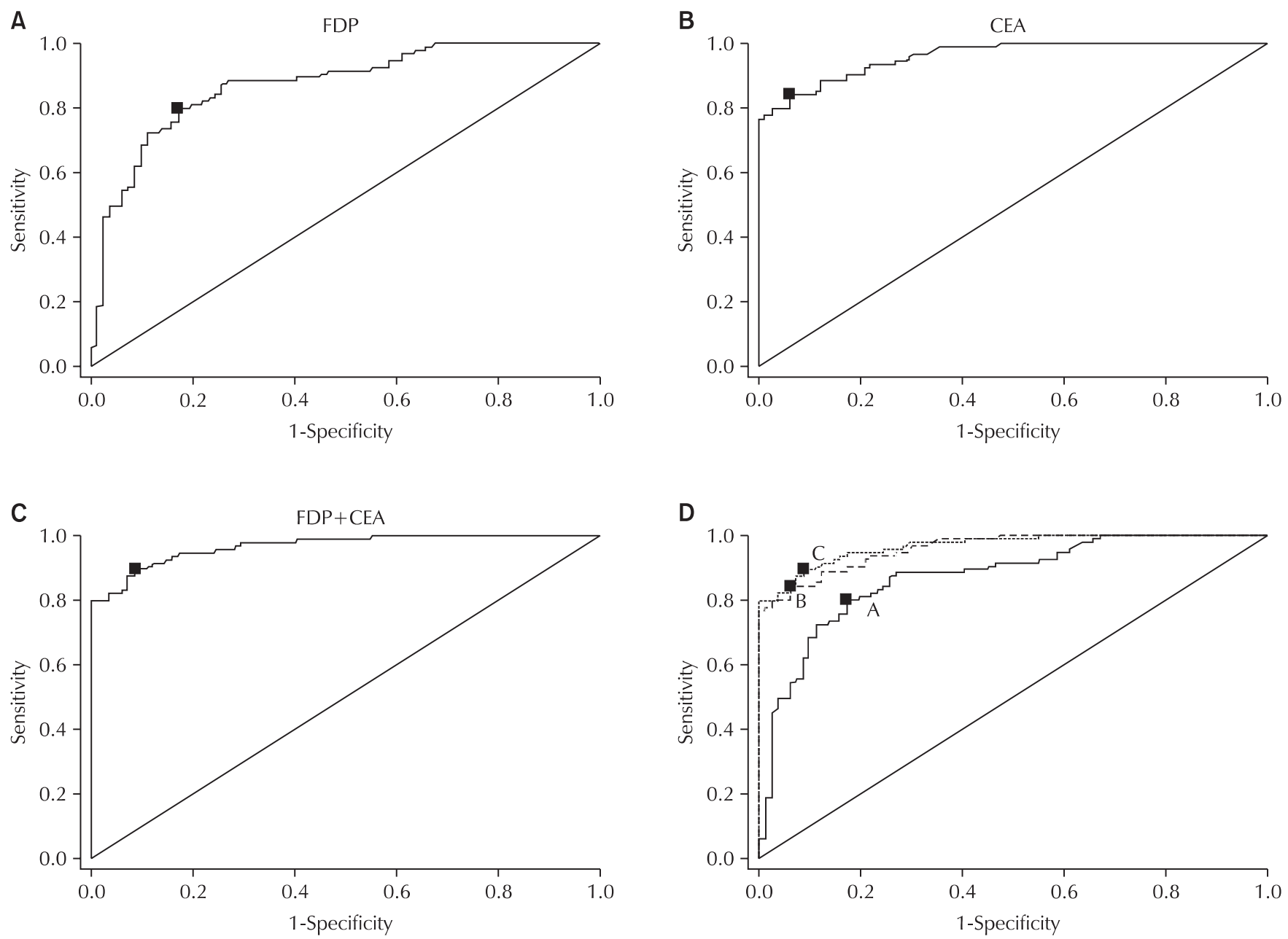

Fig. 2. Receiver operating characteristic curves of tumor markers of colon cancer. (A) Area under the curve (AUC) of fibrinfibrinogen degradation products for the diagnosis of colon cancer was 0.87 (cutoff: $0.81 \mu \mathrm{g} / \mathrm{mL}$ ). (B) AUC of carcinoembryonic antigen was 0.96 (cutoff : $3.51 \mathrm{ng} / \mathrm{mL}$ ). (C) AUC of combined FDP with CEA was 0.97. (D) AUC of all markers. Abbreviations: FDP, fibrin-fibrinogen degradation products; CEA, carcinoembryonic antigen.

Table 2. Sensitivity and specificity of markers

\begin{tabular}{lcc}
\hline Markers & Sensitivity (\%) & Specificity (\%) \\
\hline FDP & 80 & 83 \\
CEA & 84 & 94 \\
FDP + CEA & 90 & 92 \\
\hline
\end{tabular}

Abbreviations: FDP, fibrin-fibrinogen degradation products; CEA, carcinoembryonic antigen.

\section{고찰}

정상상태에서의 지혈 및 혈관 신생작용은 엄격한 조절능력 을 가지고 있는 생리학적 과정이지만 암세포가 성장할 경우에 는 이러한 조절기능이 파괴된다[12]. 국소적으로 생성된 트롬
빈은 섬유소를 형성하며, 섬유소는 종양의 혈관생성을 촉진시 키고, 종양의 성장인자로서 작용할 뿐만 아니라 섬유소의 축적 으로 인해 염증세포를 막는 방어벽을 형성함으로써 종양의 파 괴를 막아 성장을 돕는다. 또한 종양세포에서 분비된 플라스미 노겐 활성인자는 종양의 침습과 전파를 촉진시키는 플라스민 을 생성하게 되는데, 이로 인해 종양세포 존재하에서는 $\mathrm{FDP}$ 가 증가한다[13]. 즉 높아진 플라스미노겐 활성인자에 의해 플 라스민이 증가하고, 증가된 플라즈민은 종양 침윤을 촉진함과 동시에 피브린 및 $\mathrm{FDP}$ 의 증가를 초래한다.

본 연구는 이미 대장암으로 진단받은 환자와 대상질환이 없 는 대조군을 선별하여 진행된 환자-대조군 연구였다. 그러므 로 임상증상이나 징후가 없는 상태에서 질환을 감지할 수 있 는 선별적 유용성에 대한 연구로는 적합하지 않고 표지자의 진 


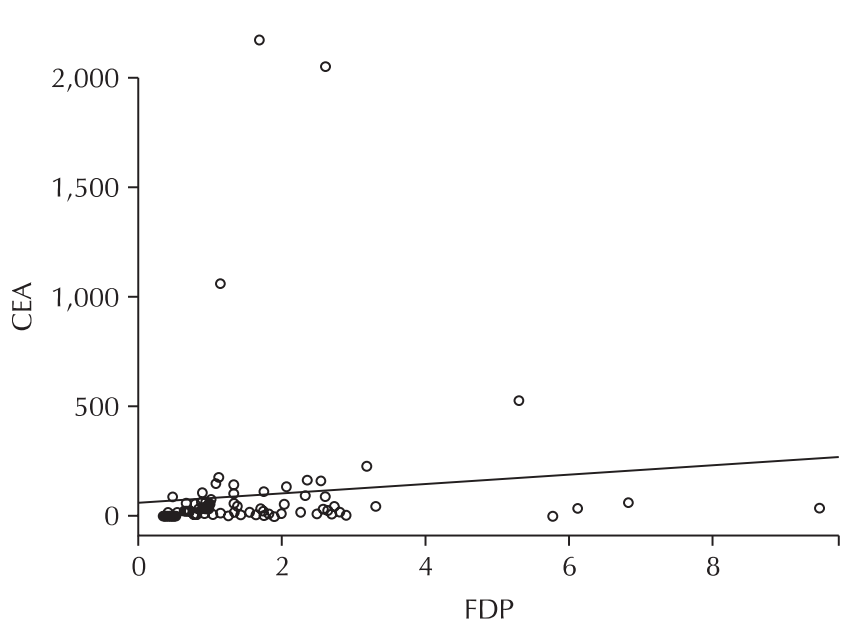

Fig. 3. Relationship between serum FDP and CEA. No correlation was demonstrated between serum FDP andCEA (Pearson's correlation test: $\mathrm{N}=95, \mathrm{R}=0.094, P=0.365$ ). Abbreviations: FDP, fibrin-fibrinogen degradation products; CEA, carcinoembryonic antigen.

단적 유용성에 대한 연구로 적합하다. 따라서 대장암의 분변 잠혈반응검사 등과 같은 선별검사보다는 대장암 특이도가 높 고, 진단 및 예후표지자로 이용되고 있는 $\mathrm{CEA}$ 와 비교 연구하 였다. 본 연구에서 혈청 $\mathrm{FDP}$ 농도가 건강대조군보다 대장암 환자군에서 더 높다는 것을 밝혔다. 이 결과는 $\mathrm{FDP}$ 가 대장암 의 잠재적 종양표지자가 될 수 있다는 근거가 된다. $\mathrm{FDP}$ 가 최 대의 대장암 진단효율(정확도 $81 \%$ )을 보이는 농도 $0.81 \mu \mathrm{g} /$ $\mathrm{mL}$ 로 컷오프를 정하였을 때, 임상적 민감도와 특이도는 각각 $80 \%, 83 \%$ 로 현재 가장 널리 쓰이는 전통적 대장암 표지자인 $\mathrm{CEA}$ 와 민감도는 비슷하나 특이도는 다소 낮았다(본 연구에서 $\mathrm{CEA}$ 의 임상적 민감도, $84 \%$; 임상적 특이도, $94 \%$; 컷오프, $3.51 \mathrm{ng} / \mathrm{mL}$ ). 또한 $\mathrm{FDP}$ 와 $\mathrm{CEA}$ 의 $\mathrm{AUC}$ 는 각각 0.87 (95\% CI, 0.82 to 0.90$), 0.96$ (95\% CI, 0.94 to 0.98)으로, 대장암 표지자로서 의미 있는 수준의 진단 성능을 보였다. $\mathrm{FDP}$ 측정 에 사용된 DR-70 진단키트의 정밀도 검증에서 변이계수의 범 위는 $3.6 \%$ (고농도)에서 $14.1 \%$ (저농도) 사이였다. 다른 연구 에서도 저농도 정도관리물질에서는 이와 비슷한 결과를 보였 는데[9], 이는 ELISA검사의 한계로 생각된다. 이러한 ELISA 검사법의 제한점을 극복하기 위해 본 연구에서는 $\mathrm{FDP}$ 농도를 두 번 반복 측정하여 평균값을 취하였다. 향후 $\mathrm{FDP}$ 의 임상적 효용을 높이기 위해서는 자동화 시스템의 도입을 통해 검사의 정밀도를 증가시켜야 할 것이다.

1995년 폐암을 검출하는 데 있어서 처음으로 $\mathrm{FDP}$ 의 임상적 유용성을 발표한 이래 대장암 표지자로서의 임상적 유용성에 대한 연구 또한 몇 차례 진행되어 왔다 [6,9,16,17]. $\mathrm{Wu}$ 등[9] 의 연구결과에 따르면 폐암, 위암, 유방암, 대장암 환자 136명
Table 3. Precision of serum fibrin-fibrinogen degradation products measurement by using the DR-70 kit

\begin{tabular}{lccc}
\hline Sample level & Mean $(\mu \mathrm{g} / \mathrm{mL})$ & SD & CV $(\%)$ \\
\hline Within-run & & & \\
Low control & 0.36 & 0.02 & 4.6 \\
High control & 3.28 & 0.22 & 6.6 \\
Low pooled serum & 0.53 & 0.02 & 3.6 \\
High pooled serum & 5.90 & 0.27 & 4.6 \\
Total-run & & & \\
Low control & 0.36 & 0.05 & 13.1 \\
High control & 3.04 & 0.21 & 6.8 \\
Low pooled serum & 0.46 & 0.07 & 14.1 \\
High pooled serum & 5.06 & 0.42 & 8.2 \\
\hline
\end{tabular}

Abbreviation: $\mathrm{CV}$, coefficient of variation.

과 277 명의 대조군의 FDP 평균값이 $13.31 \mathrm{ng} / \mathrm{mL}, 1.66 \mathrm{ng} /$ $\mathrm{mL}$ 로 전체 암 환자군이 의미 있게 높았으며, 이 가운데 대장 암 환자 6 명의 평균값은 $9.23 \mathrm{ng} / \mathrm{mL}$ 였다. 이때 $95 \%$ 특이도 를 보이는 컷오프에서 대장암의 민감도는 $66.7 \%$ 였다. 대장암 의 진단에 있어서 $\mathrm{FDP}$ 의 유용성에 대해 발표된 또 다른 연구 에서도 건강대조군보다 대장암 환자군의 $\mathrm{FDP}$ 중앙값이 통계 적으로 유의하게 높았다[17]. 국내에서도 이와 비슷한 연구 발표가 한번 있었는데, Lee 등[6]은 대장암을 포함하여 유방 암, 간세포암, 난소암, 위암, 갑상선암 등의 암종과 건강대조군 의 $\mathrm{FDP}$ 평균값을 비교하였다. 이 연구에서도 암 환자들의 평 균값 역시 건강대조군에 비해 유의하게 높았으나, 대장암 환 자 5 명의 평균값은 건강대조군과 의미 있는 차이를 보이지 않 았고, 이 연구에서 $\mathrm{FDP}$ 의 대장암 진단 민감도는 $80 \%$, 특이도 는 $70.1 \%$ 였다(컷오프 $1.09 \mathrm{ng} / \mathrm{mL}$ ). 전통적인 대장암 종양표 지자인 $\mathrm{CEA}$ 와 비교한 연구도 있었는데, 30 명의 대장암 환자 와 100 명의 대조군을 비교한 연구에서 $\mathrm{FDP}$ 의 민감도는 $80 \%$ 로 CEA 43.3\%보다 높은 민감도를 보였다[16]. 위의 연구들 에서는 대장암 환자군의 표본 수가 각각 6 명, 30 명, 44 명, 5 명, 30 명으로 소규모였던 것에 비해, 본 연구에서는 대장암 환자 표본 수가 95명으로 보다 정확한 모수적 검정을 시행할 수 있 었다. 본 연구에서 $\mathrm{FDP}$ 와 $\mathrm{CEA}$ 사이의 연관성은 관찰되지 않 았는데(Fig. 3) 이것은 두 표지자가 대장암 환자에서 발현되 는 기전이 다르기 때문으로 생각되며 두 표지자를 조합했을 때 임상적 민감도가 $90 \%$ 로 증가되었다(Table 3). FDP와 CEA 를 병용한 또 다른 연구에서도 $80 \%$ 특이도를 보일 때 $\mathrm{FDP}$, $\mathrm{CEA}$ 단독 민감도 $57.5 \%, 53.8 \%$ 에서 두 표지자를 병용하였 을 때 민감도가 $65.1 \%$ 로 증가하는 결과를 보였다[22]. 병용 시 민감도가 증가하는 것은 본 연구와 유사하나 그 값에 상당 
히 차이가 있는 것은 $\mathrm{CEA}$ 측정방법이 본 연구와 달리 ELISA 를 사용했다는 점과 환자 중증도에 차이가 있었을 가능성을 생 각해 볼 수 있다.

본 연구의 제한점으로는 대장암 환자군과 건강대조군 간의 성비와 연령분포의 차이를 들 수 있다. Lee 등〔6]에 따르면 연 령이 높을수록 $\mathrm{FDP}$ 의 평균값이 증가한다고 하였으므로 본 연 구에서 군 간의 연령차이가 $\mathrm{FDP}$ 평균값에 영향을 끼쳤을 가 능성이 있다. 하지만 암 환자군 내에서 중앙연령 67 세를 기준 으로 하여 그 이상 연령군과 이하 연령군 간 $\mathrm{FDP}$ 평균값의 차 이는 없었고, two-way ANOVA 검증을 통하여 FDP 수치가 성별에 의해 차이가 없음을 확인하였다. 또 다른 제한점으로는 대장암 환자군에서 치료 전후의 $\mathrm{FDP}$ 수치를 측정하지 못하여 치료 전후의 모니터 표지자로서 $\mathrm{FDP}$ 의 역할분석을 하지 못한 것이다.

$\mathrm{FDP}$ 의 일종인 $\mathrm{D}-$ 이합체와 대장암 환자의 생존율에 관한 연구들이 발표되었는데, Oya 등[14]의 연구에서는 수술 전 높 은 수치의 D-이합체를 보인 환자들이 낮은 수치를 보인 환자 들에 비해 치료적 절제술 후 생존기간이 감소하였다. 간 전이 를 보이는 대장암 환자군에서 전이를 보이지 않은 환자군에서 보다 유의하게 높은 D-이합체 수치를 보였으며[15], 수술 전 D-이합체의 수치가 수술 후 또는 전신적 항암화학요법 치료 후의 대장암 환자 생존율에 의미 있는 영향을 미친다는 보고가 있었으므로[18-20], 향후 예후지표로서의 의미를 확인하기 위 해 치료 전후에 대상자들을 추적하여 충분한 기간 연구를 진행 해야 할 것이다.

대장암 정복을 위해서는 무엇보다 조기검진이 중요하며 이 는 무증상 평균 위험군에서 대장암 선별검사를 통해 암을 조 기에 발견하여 사망률을 감소시킨다는 여러 연구들을 통해 확 인할 수 있다[23-26]. 우리나라의 대장암 조기검진율은 연간 $2.4 \%$ 증가를 보이고 있는데, 2012년 조기검진율은 $65.8 \%$ 였 지만 이는 위암이나 유방암의 조기검진율에 비해 낮은 수치다 (각각 $77.9 \%, 82.9 \%$ ) [27]. 이것은 비록 대장암의 조기검진 사업이 예전에 비해 활성화 되었으나, 대장내시경이나 대변검 사의 경우 시행의 불편함 때문에 검사순응도가 낮은 이유일 것 이며 이를 대신할 수 있는 선별방법이 절실히 필요하다. $\mathrm{FDP}$ 가 대장암 선별검사로서 사용 가능한지를 알아보기 위해 향후 에는 전암단계의 환자군까지 범위를 확장시켜 충분한 기간 연 구를 진행해야 할 것이다.

결론적으로, 본 연구의 의의는 대장암진단에 있어서 $\mathrm{FDP}$ 가 새로운 표지자 역할을 할 수 있으며, 전통적 표지자인 $\mathrm{CEA}$ 에 혈청 $\mathrm{FDP}$ 를 병합함으로써 특이도의 큰 손실 없이 임상적 민 감도를 높일 수 있음을 밝힌 데에 있다.

\section{REFERENCES}

1. Jemal A, Siegel R, Ward E, Hao Y, Xu J, Thun MJ. Cancer statistics, 2009. CA Cancer J Clin 2009;59:225-49.

2. Jung KW, Won YJ, Kong HJ, Oh CM, Seo HG, Lee JS. Cancer statistics in Korea: incidence, mortality, survival and prevalence in 2010. Cancer Res Treat 2013;45:1-14.

3. Kim SE, Hong SP, Kim HS, Lee BI, Kim SH, Hong SN, et al. A Korean national survey for colorectal cancer screening and polyp diagnosis methods using web-based survey. Korean J Gastroenterol 2012;60:26-35.

4. Locker GY, Hamilton S, Harris J, Jessup JM, Kemeny N, Macdonald JS, et al. ASCO 2006 update of recommendations for the use of tumor markers in gastrointestinal cancer. J Clin Oncol 2006;24:5313-27.

5. Li X, Qiao Z, Long X, Wei J, Cheng Y. Serum concentration of AMDL DR-70 for the diagnosis and prognosis of carcinoma of the tongue. Br J Oral Maxillofac Surg 2005;43:513-5.

6. Lee KH, Cho DH, Kim KM, Kim SM, Lee DJ. Meaning of the DR-70TM immunoassay for patients with the malignant tumor. Immune Network 2006;6:43-51.

7. Ding L, Ping S, Jingmei Y. Application of tumor marker of DR- $70^{\circ}$ in the diagnosis of malignant tumors. Chongqing Med J 1999;28:1-3.

8. Lin SZ, Chen CC, Lee KC, Tseng CW, Lin HY, Chen $\mathrm{YC}$, et al. DR-70 immunoassay for the surveillance of hepatocellular carcinoma. J Gastroenterol Hepatol 2012; 27:547-52.

9. Wu D, Zhou X, Yang G, Xie Y, Hu M, Wu Z, et al. Clinical performance of the AMDL DR-70 immunoassay kit for cancer detection. J Immunoassay 1998;19:63-72.

10. Dirix LY, Salgado R, Weytjens R, Colpaert C, Benoy I, Huget $\mathrm{P}$, et al. Plasma fibrin D-dimer levels correlate with tumour volume, progression rate and survival in patients with metastatic breast cancer. Br J Cancer 2002;86:38995.

11. Ward DG, Wei W, Buckels J, Taha AM, Hegab B, Tariciotti $\mathrm{L}$, et al. Detection of pancreatic adenocarcinoma using circulating fragments of fibrinogen. Eur J Gastroenterol Hepatol 2010;22:1358-63.

12. Altiay G, Ciftci A, Demir M, Kocak Z, Sut N, Tabakoglu 
E, et al. High plasma D-dimer level is associated with decreased survival in patients with lung cancer. Clin Oncol (R Coll Radiol) 2007;19:494-8.

13. Unsal E, Atalay F, Atikcan S, Yilmaz A. Prognostic significance of hemostatic parameters in patients with lung cancer. Respir Med 2004;98:93-8.

14. Oya M, Akiyama Y, Okuyama T, Ishikawa H. High preoperative plasma D-dimer level is associated with advanced tumor stage and short survival after curative resection in patients with colorectal cancer. Jpn J Clin Oncol 2001;31:388-94.

15. Blackwell K, Hurwitz H, Lieberman G, Novotny W, Snyder S, Dewhirst M, et al. Circulating D-dimer levels are better predictors of overall survival and disease progression than carcinoembryonic antigen levels in patients with metastatic colorectal carcinoma. Cancer 2004;101:77-82.

16. Kerber A, Trojan J, Herrlinger K, Zgouras D, Caspary WF, Braden B. The new DR-70 immunoassay detects cancer of the gastrointestinal tract: a validation study. Aliment Pharmacol Ther 2004;20:983-7.

17. Rucker P, Antonio SM, Braden B. Elevated fibrinogenfibrin degradation products (FDP) in serum of colorectal cancer patients. Anal Lett 2004;37:2965-76.

18. Kilic M, Yoldas O, Keskek M, Ertan T, Tez M, Gocmen E, et al.. Prognostic value of plasma D-dimer levels in patients with colorectal cancer. Colorectal Dis 2008;10: 238-41.

19. Small-Howard AL, Harris H. Advantages of the AMDLELISA DR-70 (FDP) assay over carcinoembryonic antigen (CEA) for monitoring colorectal cancer patients. J Immunoassay Immunochem 2010;31:131-47.
20. Yamamoto M, Yoshinaga K, Matsuyama A, Iwasa T, Osoegawa A, Tsujita E, et al. Plasma D-dimer level as a mortality predictor in patients with advanced or recurrent colorectal cancer. Oncology 2012;83:10-5.

21. Mathew BC, Biju RS, Thapalia N. An overview of electrochemiluminescent (ECL) technology in laboratory investigations. Kathmandu Univ Med J (KUMJ) 2005;3: 91-3.

22. Shimwell NJ, Wei W, Wilson S, Wakelam MJ, Ismail T, Iqbal T, et al. Assessment of novel combinations of biomarkers for the detection of colorectal cancer. Cancer Biomark 2010;7:123-32.

23. Levin B, Lieberman DA, McFarland B, Smith RA, Brooks D, Andrews KS, et al. Screening and surveillance for the early detection of colorectal cancer and adenomatous polyps, 2008: a joint guideline from the American Cancer Society, the US Multi-Society Task Force on Colorectal Cancer, and the American College of Radiology. CA Cancer J Clin 2008;58:130-60.

24. Lieberman DA. Clinical practice: screening for colorectal cancer. N Engl J Med 2009;361:1179-87.

25. U.S. Preventive Services Task Force. Screening for colorectal cancer: U.S. Preventive Services Task Force recommendation statement. Ann Intern Med 2008;149:627-37.

26. Whitlock EP, Lin JS, Liles E, Beil TL, Fu R. Screening for colorectal cancer: a targeted, updated systematic review for the U.S. Preventive Services Task Force. Ann Intern Med 2008;149:638-58.

27. Suh M, Choi KS, Lee YY, Jun JK. Trends in cancer screening rates among Korean men and women: results from the Korean National Cancer Screening Survey, 2004-2012. Cancer Res Treat 2013;45:86-94. 


\section{대장암 표지자로서 혈청 Fibrin-Fibrinogen Degradation} Products와 Carcinoembryonic Antigen의 비교

\section{소희진 • 홍석일 ${ }^{1,2} \bullet$ 이진경 ${ }^{1,2}$ • 장윤환 ${ }^{1,2} \cdot$ 김진희'・ 홍영준 ${ }^{1,2}$}

${ }^{1}$ 한국원자력의학원 원자력병원 진단검사의학과, ${ }^{2}$ 과학기술연합대학원대학교 원자력 암의학 전공

배경: 한국에서 대장암은 남성에서는 두 번째, 여성에서는 네 번째로 흔한 암이다. 혈청 fibrinfibrinogen degradation products (FDP)는 많은 암종에서 지혈 과정의 변화로 인해 증가 될 수 있 다. 본 연구에서는 혈청 FDP 농도와 carcinoembryonic antigen (CEA)를 비교함으로써 대장암에서 의 FDP의 진단적 유용성에 대해 알아보고자 한다.

방법: 국가방사선혈액자원은행으로부터 대장암 환자의 혈청 95검체와 건강인 혈청 82검체, 총 177 검체를 분양받았다. DR-70 진단키트(AMDL, USA)를 이용하여 FDP 농도를 측정하였고 비교검사 로는 로슈 $\mathrm{E} 170$ 장비를 이용하여 CEA를 측정하였다.

결과: 대장암군에서의 평균 FDP 농도는 $1.65 \pm 1.44 \mu \mathrm{g} / \mathrm{mL}$ (범위, $0.36-9.48 \mu \mathrm{g} / \mathrm{mL}$ )로, 건강대 조군의 평균 농도 $0.58 \pm 0.46 \mu \mathrm{g} / \mathrm{mL}$ (범위, $0.02-3.27 \mu \mathrm{g} / \mathrm{mL}$ )보다 통계적으로 유의하게 높았다 $(P<0.05)$. 대장암군에서 CEA의 평균농도는 $99.99 \pm 321.74 \mathrm{ng} / \mathrm{mL}$ (범위, $1.46-2,170.00 \mathrm{ng} / \mathrm{mL}$ )로, 건강대조군에서의 평균농도 $1.66 \pm 1.18 \mathrm{ng} / \mathrm{mL}$ (범위, $0.20-6.38 \mathrm{ng} / \mathrm{mL}$ )보다 통계적으로 유의하게 높았다 $(P<0.05)$. FDP의 컷오프를 $0.81 \mu \mathrm{g} / \mathrm{mL}$ 로 할 때, 대장암 진단의 민감도는 $80 \%$, 특이도는 $83 \%$ 였다. CEA의 경우 컷오프를 $3.51 \mathrm{ng} / \mathrm{mL}$ 로 할 때 대장암 진단의 민감도, 특이도는 $84 \%, 94 \%$ 였다. FDP receiver operating characteristic 커브의 곡선하면적(area under the curve)은 0.87, CEA 0.96 이었다. 두 표지자를 병용하였을 때 대장암 진단의 민감도는 $90 \%$, 특이도는 $92 \%$ 였다.

결론: CEA와 FDP를 병용함으로써 대장암의 진단적 민감도를 증가시킬 수 있다.

(J Lab Med Qual Assur 2014;36:99-106)

\section{교신저자: 홍영준}

우)139-706 서울시 노원구 노원로 75, 한국원자력의학원 원자력병원 진단검사의학과

Tel: 02)970-2492, Fax: 02)973-7143, E-mail: clinchem@kcch.re.kr 